\title{
Miniature queens in stingless bees: basic facts and evolutionary hypotheses
}

\author{
Márcia de F. Ribeiro ${ }^{\mathrm{a}}$, Tom WenseleERs ${ }^{\mathrm{b}}$, Pérsio de S. SANTOS FilHO ${ }^{\mathrm{a}}$, \\ Denise de A. AlvEs ${ }^{a}$ \\ a Depto. de Ecologia, Instituto de Biociências, Universidade de São Paulo, R. do Matão, trav. 14, n. 321, \\ 05508-900 São Paulo, SP, Brazil \\ ${ }^{b}$ Laboratory of Entomology, Zoological Institute, Catholic University of Leuven, Naamstraat 59, 3000 Leuven, \\ Belgium
}

Received 1 November 2005 - accepted 31 February 2006

\begin{abstract}
Some stingless bees are known to produce both large queens, reared from larger royal cells, and small "miniature" queens, reared from worker cells. Here we review what is known about miniature queens, and evaluate some major evolutionary hypotheses as to why they are produced. One hypothesis - that miniature queens are females who selfishly evade an intended worker fate - is shown to receive significant support. In particular, there is increasing evidence that the decision to become a miniature queen may be under genetic control of the developing females themselves. In addition, data from several species show that females gain significant fitness benefits from doing so, since miniature queens are frequently observed heading colonies and often are as productive as normal-sized queens. On the other hand, in some species miniature queens have a reduced fecundity or may have lower chances of being chosen as a new queen. This shows that the strategy may also have costs. Queens of the genus Melipona, which are also reared from worker-sized cells, are suggested to have the same evolutionary origins as miniature queens.
\end{abstract}

queen dimorphism / miniature queens / stingless bees / caste fate conflict / Apidae / Meliponini

\section{INTRODUCTION}

Among the social Hymenoptera, stingless bees (Apidae, Meliponini) have unusually great variability in the mechanisms by which caste is determined and queens are reared (Engels and Imperatriz-Fonseca, 1990; Fig. 1). In the genus Melipona, queens and workers are the same size and are reared from identical, mass-provisioned cells (Figs. 1a, 2h). Caste is determined by the actual developing larvae themselves (Kerr, 1950, 1969; Bourke and Ratnieks, 1999) and queens and workers are produced in a genetically de-

Corresponding author: M. de F. Ribeiro, marib@ufc.br

Present address: Depto. de Zootecnia, Universidade Federal do Ceará - UFC, Bloco 809 Campus do PICI, 60021-970 Fortaleza, CE, Brazil. termined, but slightly plastic, ratio (Kerr, 1950, 1969; Velthuis and Sommeijer, 1991; Ratnieks, 2001). By contrast, in all other genera of stingless bees, e.g. Trigona, caste is nutritionally rather than genetically determined and queens are normally produced from larger, specially constructed royal cells which are provisioned with more, but samequality, food (Darchen and Delage-Darchen, 1971; Camargo, 1972; Hartfelder and Engels, 1989; Engels and Imperatriz-Fonseca, 1990; Figs. 1b, 2a). A slight variation on this system occurs in the genera Frieseomelitta and Leurotrigona. In these, no special royal cells are constructed. Instead, female larvae develop as queens by biting through their cell wall and consuming the provision mass of a neighbouring cell in addition to their own (Terada, 1974; Faustino et al., 2002; Fig. 1c). 
a

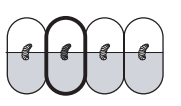

b

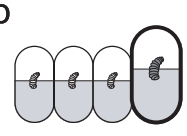

C

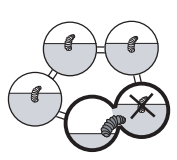

Figure 1. Mechanisms of queen rearing in stingless bees. (a) In the genus Melipona, queens and workers are the same size and develop in identical, similarly provisioned cells. No special royal cells are constructed. (b) In most other genera of stingless bees, e.g. Trigona, caste is determined by nutrition and queens are reared from larger royal cells, constructed at the periphery of the comb. (c) In the two genera Frieseomelitta and Leurotrigona, caste is also determined by nutrition, but no special royal cells are constructed. Instead, female larvae develop as queens by biting through their cell wall and consuming the provision mass of a neighbouring cell in addition to their own. A mechanism intermediate between (a) and (b) is seen in the genera Nannotrigona, Plebeia and Schwarziana. Here, queens are normally reared from royal cells, but females also have the ability to develop as miniature queens when reared in worker cells. Bold lines = queen cells; fine lines $=$ worker cells.

In addition to this three basic mechanisms there are also a number of genera where queens can both be reared from small worker cells and large royal cells simultaneously (Fig. 2a-c). The queens reared from worker cells are much smaller than normal-sized queens and are referred to as "miniature" or "dwarf" queens (Engels and ImperatrizFonseca, 1990; Imperatriz-Fonseca et al., 1997; Bourke and Ratnieks, 1999; Ribeiro, 2004a; Ribeiro et al., 2006; Wenseleers et al., 2005). Although the presence of miniature queens has not been systematically investigated in stingless bees, they have now been recorded in nine species: Cephalotrigona capitata (von Ihering, 1903; Schwarz, 1948), Plebeia julianii (Juliani, 1967), Schwarziana quadripunctata (Camargo, 1974; Costa, 1977; Imperatriz-Fonseca and Darakjian, 1993; Nogueira-Ferreira et al., 2000; Ribeiro and Alves, 2001; Wenseleers et al., 2005), $P$. remota (Imperatriz-Fonseca et al., 1975; Ribeiro et al., 2003; Ribeiro et al., 2006), $P$. emerina (Kleinert, pers. comm.), P. droryana (Imperatriz-Fonseca, pers. comm.), P. mosquito (Freitas and Paxton, pers. comm.),

P. pugnax (in litt.) (Wenseleers and Alves, unpubl. data) and Nannotrigona testaceicornis (Imperatriz-Fonseca et al., 1994; ImperatrizFonseca et al., 1997). The rearing of queens from both worker cells and specialised royal cells is very interesting, as it exemplifies a situation that is exactly intermediate between the Melipona and Trigona type system. Despite this, miniature queens have long been neglected in the literature. The aim of this paper is to rectify this situation, and to review the basic facts about miniature queens and examine some of the major theories for why they are produced. As we will show, miniature queens are not mere curiosities but provide fundamental insight into how and why the different caste determination systems in stingless bees first evolved. In addition, we argue that miniature queens provide among the best support for the idea that there is a conflict over the caste fate of individuals in insect societies (Bourke and Ratnieks, 1999; Ratnieks et al., 2006). In particular, it corroborates the theory that individual females can benefit from evading an intended worker fate by developing as small-sized queens (Bourke and Ratnieks, 1999; Wenseleers et al., 2003; Ratnieks et al., 2006). Although the evidence for this theory was once controversial, we show that it is now well supported and that it can explain many of the facts about miniature queens.

\section{WHY ARE MINIATURE QUEENS PRODUCED?}

The most fundamental question is: why are miniature queens produced in the first place? In recent years, three major theories have been proposed (Tab. I):

\subsection{Hypothesis 1: Selfish evasion of a worker fate}

A first ultimate explanation for the existence of miniature queens was proposed by Bourke and Ratnieks (1999). They noted that in an insect society, workers have a much reduced reproductive potential compared to queens. Hence, any individual would benefit if it could develop as a queen rather than a 

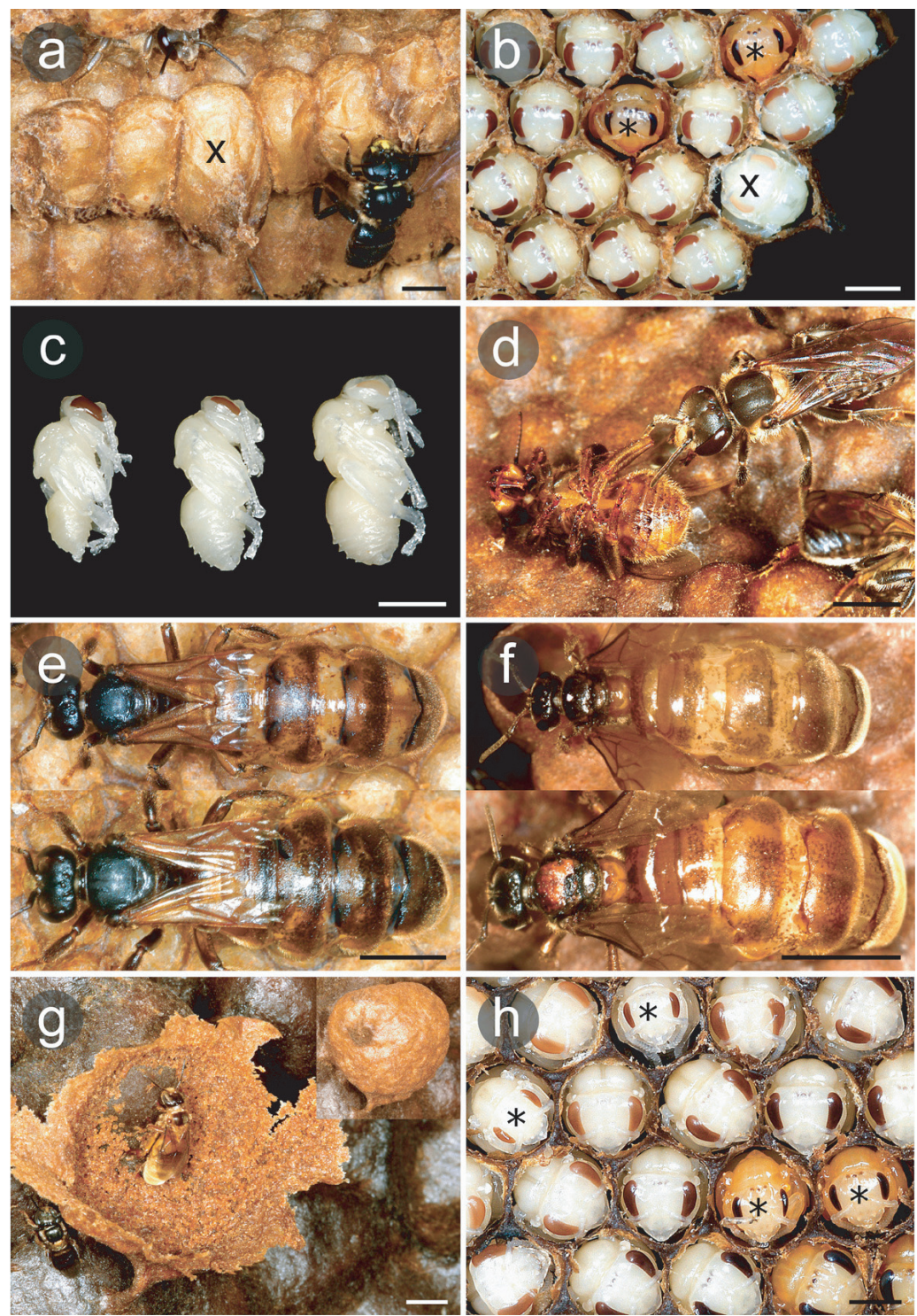

Figure 2. Miniature queens in stingless bees. (a) In Schwarziana quadripunctata, queens are normally reared from larger, specially constructed royal cells (x). The smaller cells in the comb are used to rear workers and males. (b) Uncapping of the comb in (a), however, shows that two females reared in worker cells developed as miniature queens $(*)$. The royal cell contains a normal-sized queen (x). (c) Miniature queens (middle) can be distinguished from workers by their smaller heads and eyes and their lack of pollen baskets. They are approximately the same size as workers (left), but are much smaller than normal-sized queens (right). (d) Workers sometimes discriminate against miniature queens. Here, a worker (right) kills a miniature $S$. quadripunctata queen (left) that has recently emerged from her cell. (e-f) Miniature queens (top) of S. quadripunctata (e) and Plebeia remota (f) can successfully head colonies despite being significantly smaller than normal-sized queens (bottom). (g) A virgin queen of P. remota is stored in a wax "prison" for potential later use. The prison is normally closed (inset) but is here opened up to reveal the queen inside. (h) Melipona queens (*) are also reared in worker-sized cells and may be homologous to miniature queens. All photos are by Wenseleers. (Scale bars, $2.5 \mathrm{~mm}$ ). 
Table I. The three main hypotheses for why miniature queens are produced and their supporting evidence.

\begin{tabular}{|c|c|c|}
\hline \multirow[t]{4}{*}{$\begin{array}{l}\text { Hypothesis } \\
\text { 1. Caste conflict hypothesis: } \\
\text { becoming a miniature queen } \\
\text { is a selfish strategy of de- } \\
\text { veloping females that allows } \\
\text { them to become queens even } \\
\text { when reared from worker } \\
\text { cells }^{\mathrm{a}}\end{array}$} & $\begin{array}{l}\text { Predictions or assumptions } \\
\text { Females have the ability to } \\
\text { determine their own caste } \\
\text { fate (self-determination) }{ }^{\mathrm{a}}\end{array}$ & $\begin{array}{l}\text { Supporting evidence } \\
\text { Miniature queens and work- Although the quantity of } \\
\text { ers generally have similar food that miniature queens } \\
\text { weights, implying that fe- develop onto may be the } \\
\text { males can become miniature same as workers, the quality } \\
\text { queens even with worker- of the food may be different }{ }^{\mathrm{c}} \\
\text { levels of nutrition (Fig. } 3)^{\mathrm{b}}\end{array}$ \\
\hline & $\begin{array}{l}\text { Females gain fitness benefits } \\
\text { from developing as miniature } \\
\text { queens }\end{array}$ & $\begin{array}{l}\text { Miniature queens are re- } \\
\text { productively successful and } \\
\text { frequently head colonies } \\
(\text { Tab. II })^{\mathrm{d}}\end{array}$ \\
\hline & $\begin{array}{l}\text { Many females should em- } \\
\text { ploy this strategy resulting in } \\
\text { the produc-tion of miniature } \\
\text { queens in excess of colony } \\
\text { needs }\end{array}$ & $\begin{array}{l}\text { Miniature queens can be Normal-sized queens may } \\
\text { produced at high rates and also be killed by workers if } \\
\text { tend to be overproduced they are not needed } \\
\text { relative to normal-sized } \\
\text { queens }(\text { Tab. II) }\end{array}$ \\
\hline & & $\begin{array}{l}\text { Excess miniature queens } \\
\text { are killed by workers }\end{array}$ \\
\hline
\end{tabular}

2. Insurance hypothesis: miniature queens are an insurance for potential use when the mother queen dies ${ }^{\mathrm{i}}$

3. Developmental mistake hypothesis: miniature queens are nonadaptive developmental mistakes ${ }^{\mathrm{k}}$
The storage of normal-sized virgin queens in wax "prisons" is already a very effective mechanism to ensure the availability of reserve queens $^{\mathrm{j}}$

Females in royal cells also Giant workers are very rare ${ }^{1}$, occasionally develop as gi- but dwarf queens may be ant workers. These have no quite common ${ }^{\mathrm{f}}$ obvious adaptive value, and also reflect a developmental mistake ${ }^{1}$

\begin{tabular}{|c|c|c|}
\hline $\begin{array}{l}\text { Miniature queens are not re- } \\
\text { productively successful }\end{array}$ & None & $\begin{array}{l}\text { Miniature queens can suc- } \\
\text { cessfully head colonies } \\
\text { and so their production is } \\
\text { adaptive }^{\mathrm{d}}\end{array}$ \\
\hline $\begin{array}{l}\text { Miniature queens are pro- } \\
\text { duced as a result of a slight } \\
\text { overprovisioning of some } \\
\text { cells }\end{array}$ & $\begin{array}{l}\text { In some species it has been } \\
\text { shown that females develop } \\
\text { as small-sized queens if cells } \\
\text { are slightly overprovisioned } \\
\text { with food }^{\mathrm{n}}\end{array}$ & $\begin{array}{l}\text { Miniature queens generally } \\
\text { have a similar weight as } \\
\text { workers, implying they did } \\
\text { not receive more food as a } \\
\text { larva (Fig. } 3)^{b} \text { or the possibil- } \\
\text { ity of a high quality food }\end{array}$ \\
\hline
\end{tabular}

${ }^{a}$ Bourke and Ratnieks, 1999; Wenseleers et al., 2003, 2004a, 2005; ${ }^{\mathrm{b}}$ N. testaceicornis: Imperatriz-Fonseca et al., 1997, mean fresh weight newly emerged miniature queens: $7.67 \mathrm{mg}$ (S.D. 0.87, $\mathrm{n}=8$ ), mean fresh weight of workers: $7.13 \mathrm{mg}$ (S.D. 0.72, $\mathrm{n}=17$ ); S. quadripunctata and P. remota: see Figure 3; ${ }^{\mathrm{c}}$ Castilho-Hyodo, 2001; Ribeiro 2004a; ${ }^{\mathrm{d}}$ Ribeiro and Alves, 2001; Ribeiro et al., 2006; Wenseleers et al., 2005; ${ }^{\mathrm{e}}$ Bourke and Ratnieks, 1999; Wenseleers et al., 2004a; ${ }^{\mathrm{f}}$ In P. mosquito $40 \%$ of all females in worker cells have been observed to develop as miniature queens, which represents a vast overproduction (Freitas and Paxton, pers. comm.); in N. testaceicornis 5 to 8 miniature queens were found in a single comb (Imperatriz-Fonseca et al., 1997); in P. remota and S. quadripunctata miniature queens may represent a significant proportion of all queens produced (Tab. II, Ribeiro et al., 2003; Wenseleers et al., 2005); ${ }^{\mathrm{g}}$ Engels and Imperatriz-Fonseca, 1990; Imperatriz-Fonseca, 1990; Imperatriz-Fonseca and Zucchi, 1995; Wenseleers et al., 2005; ${ }^{\mathrm{h}}$ Ribeiro, unpublished data; ${ }^{\mathrm{i}}$ Nogueira-Ferreira et al., 2000; ${ }^{\mathrm{j}}$ Moure et al., 1958; ${ }^{\mathrm{k}}$ Campos and Costa, 1989; Nogueira-Ferreira et al., 2000; ${ }^{1}$ Imperatriz-Fonseca et al., 1975; ImperatrizFonseca, 1976; Engels and Imperatriz-Fonseca, 1990; ${ }^{\mathrm{m}}$ Nogueira-Ferreira et al., 2000; ${ }^{\mathrm{n}}$ Darchen and Delage-Darchen, 1971 ; Campos et al., 1986; Campos and Costa, 1989. 
worker. Normally, the caste fate of a developing individual is out of her own control, being socially imposed by the amount or quality of food she is fed as a larva by the adult workers (Wilson, 1971). However, one way to overcome social control would be to develop as a miniature queen even when fed with an amount of food that is normally only sufficient to develop as a worker (Bourke and Ratnieks, 1999). This theory is known as the caste conflict hypothesis (Tab. I).

One assumption of this theory is that females can determine their own caste fate ("self determination"), that is that females can control themselves, through their genetics, whether to develop as a queen or a worker (Bourke and Ratnieks, 1999). Self determination can be tested by comparing the weight of miniature queens and workers. If their weights are the same then this means that they must have ingested the same amount of food as a larva and that caste development is not constrained by nutrition (Wenseleers et al., 2005; cf. Kerr, 1969; Wenseleers et al., 2004b). The caste conflict hypothesis also rests on the assumption that miniature queens are reproductively competent and that they can successfully head colonies, as otherwise the strategy would not pay off (Wenseleers et al., 2004a).

A clear prediction of the caste conflict hypothesis is that a large proportion of females can be selected to develop as queens, and that this could result in miniature queen overproduction (Wenseleers et al., 2004a). A formal kin selection model showed that the expected level of excess queen production can be quite high, and that under single mating up to $20 \%$ of all females in worker cells can be selected to become miniature queens (Wenseleers et al., 2004a). However, this is a maximum figure. If miniature queens have a reduced fecundity or a lower probability than a normal-sized queen of establishing a new colony then the expected excess is less, and far fewer, e.g. just $1 \%$, of the females are selected to develop as queens (Wenseleers et al., 2004a). Even 1\%, however, would represent a significant excess. Stingless bees reproduce by swarming and for this only few queens are needed as only one queen is required to head a swarm and swarms are produced only occasionally.
The caste conflict hypothesis has also been used to explain why in Melipona queens are overproduced. Melipona queens are the same size as workers, and this gives individuals the power to determine their own caste fate (Kerr, 1950, 1969; Ratnieks, 2001; Wenseleers et al., 2003, 2004b; Wenseleers and Ratnieks, 2004). In addition, queens in Melipona do not have to compete with potentially superior larger queens reared from royal cells. In line with prediction, levels of queen production in Melipona are close to the expected maximum, around 20\%, or slightly lower (Kerr, 1950, 1969; Moo-Valle et al., 2001; Wenseleers et al., 2003, 2004b; Sommeijer et al., 2003; Wenseleers and Ratnieks, 2004).

\subsection{Hypothesis 2: As an insurance strategy}

A second hypothesis, proposed by Nogueira-Ferreira et al. (2000) is that miniature queens are produced as an insurance, for potential use when the mother queen dies. A criticism of this hypothesis is that many species of trigonine bees already have a very effective insurance mechanism in the form of wax chambers or "prisons" in which virgin queens are stored for potential later use (Moure et al., 1958; Nogueira-Neto, 1958; Juliani, 1962; Camargo, 1974; ImperatrizFonseca et al., 1975; Imperatriz-Fonseca and Kleinert-Giovannini, 1989; Engels and Imperatriz-Fonseca, 1990; Imperatriz-Fonseca and Darakjian, 1993; Imperatriz-Fonseca and Zucchi, 1995; van Benthem et al., 1995). Hence, it is not clear why they would need miniature queens as an additional insurance mechanism. The insurance hypothesis has also been used as a potential explanation for the high levels of queen production in Melipona (Michener, 1974; Engels and ImperatrizFonseca, 1990; Koedam et al., 1995), although the caste conflict hypothesis is considered a more parsimonious explanation for this (Wenseleers et al., 2003, 2004b).

\subsection{Hypothesis 3: Developmental mistakes}

A third and final hypothesis is that miniature queens are nonadaptive and are produced 
as a result of mistakes in development or erratic cell provisioning (Campos and Costa, 1989; Nogueira-Ferreira et al., 2000; Tab. I). This hypothesis is based on the fact that in several species larvae develop as queens even if they are provisioned with an amount of food that is only slightly larger than a normal worker cell provision (Darchen and DelageDarchen, 1971; Camargo, 1972; Campos et al., 1986; Campos and Coelho, 1993). Therefore, miniature queens could be produced from worker cells that are accidentally overprovisioned. Another argument for the developmental mistake hypothesis is that females in royal cells also sometimes develop as giant workers (Imperatriz-Fonseca et al., 1975; Imperatriz-Fonseca, 1976; Engels and Imperatriz-Fonseca, 1990). Giant workers have no obvious adaptive value, and illustrate that developmental errors can at least occur in the other direction, i.e. that individuals that are meant to become queens can occasionally develop as workers.

\section{EMPIRICAL DATA ON MINIATURE QUEENS}

Over the last eight years, two species which produce miniature queens, Schwarziana quadripunctata and Plebeia remota, have been studied by us in great detail at the Bee Laboratory in São Paulo, Brazil (Tab. II). Below we review what is known about miniature queens in these two model systems and evaluate how the available evidence supports or refutes the three fore mentioned hypotheses (Tab. I). We also briefly review the more limited data on miniature queens in other species.

\subsection{Schwarziana quadripunctata}

Camargo (1974) was the first to discover that in the underground nesting stingless bee $S$. quadripunctata small queens may be reared from scattered locations in the centre of the comb, in a fashion similar to Melipona (Fig. 2b, h). Imperatriz-Fonseca and KleinertGiovanni (1989) later observed that larger queens may also be reared from typical royal cells, constructed at the periphery of the comb
(Fig. 2a). Although early studies agreed on the fact that there was significant variation in the size of virgin queens, it was not clear whether the production of small queens was adaptive. Camargo (1974) claimed that miniature queens were only reared from cells that were slightly larger than the surrounding worker cells. This led to the idea that miniature queens were perhaps produced merely as a result of the overprovisioning of some cells, or as a result of developmental errors, since very occasionally giant workers were also found emerging from royal cells, as mentioned above (Hypothesis 3). The experiments of Campos and Costa (1989) initially seemed to support the nonadaptive mistake hypothesis. If female larvae were nourished with $140 \%$ the amount of a normal worker cell provision, 5\% developed as queens.

Imperatriz-Fonseca and KleinertGiovannini (1989) were the first to clearly reject the nonadaptive mistake hypothesis, by showing that miniature Schwarziana queens were reproductively competent: one out of 7 colonies examined was found to be headed by a miniature queen (Fig. 2e). Later, our own studies based on detailed morphometry of live mother queens showed that 12 out of 54 colonies $(22 \%)$ were headed by small queens (Ribeiro and Alves, 2001; Wenseleers et al., 2005). On the other hand, three colonies examined by Nogueira-Ferreira et al. (2000) were all headed by large queens. Overall, miniature queens have thus been found heading 13 of the $64(20 \%)$ colonies examined (Tab. II). This shows that miniature queens are reproductively successful and that an adaptive hypothesis needs to be sought for their production (Hypothesis 1 or 2).

Wenseleers et al. (2005) specifically tested the theory that miniature queens arise as a result of a selective pressure on larvae to evade an intended worker fate (Hypothesis 1). In support of the theory, Wenseleers et al. (2005) found that dwarf queen and worker pupae had the same weight, confirming an earlier study (Imperatriz-Fonseca and Zucchi, 1995), whereas normal-sized queen pupae were ca. twice as heavy (Figs. 2c, 3). This demonstrated that miniature queens were meant to become workers and that individual females in worker 
Table II. Data on miniature queens in two of the best studied species, Schwarziana quadripunctata and Plebeia remota.

\begin{tabular}{|c|c|c|}
\hline & S. quadripunctata & P. remota \\
\hline \multicolumn{3}{|l|}{ Rate of production } \\
\hline$\%$ of females in small cells that develop & $0.6 \%{ }^{\mathrm{a}}$ & $0.01^{\mathrm{b}}-0.2 \%^{\mathrm{c}}$ \\
\hline as miniature queens & up to $7 \%(\max .)^{\mathrm{d}}$ & up to $44 \%(\max .)^{\mathrm{c}, \mathrm{d} *}$ \\
\hline$\%$ of virgin queens reared that & $86 \% \mathrm{e}$ & $11^{\mathrm{b}}-53 \%{ }^{\mathrm{c} *}$ \\
\hline are miniature & $86 \%{ }^{\mathrm{e}}$ & $15-45 \% \mathrm{f}$ \\
\hline \multicolumn{3}{|l|}{ Evidence for self-determination of caste fate } \\
\hline Miniature virgin queens same weight as workers? & yes $^{\mathrm{g}}$ & in some colonies ${ }^{\mathrm{h}}$ \\
\hline Location of miniature queens in comb & randomly distributed ${ }^{g}$ & no data \\
\hline \multicolumn{3}{|l|}{ Reproductive success of miniature mated queens } \\
\hline$\%$ of colonies headed by miniature queens & $20 \%{ }^{\mathrm{i}}$ & $14 \% \mathrm{j}$ \\
\hline Reduced fecundity? & yes $^{\mathrm{k}}$ & nol ${ }^{1}$ \\
\hline Reduced lifespan? & no data & $\mathrm{no}^{\mathrm{m}}$ \\
\hline Reduced probability of being chosen as a new queen? & yes $^{\mathrm{n}}$ & perhaps $^{\circ}$ \\
\hline
\end{tabular}

a Among 11574 female pupae collected from 90 combs and 19 colonies, 11495 were workers, 68 miniature queens and 11 normal-sized queens reared (Wenseleers et al., 2005); ${ }^{\mathrm{b}}$ Estimate based on the rate at which queens are reared from combs, as reported by Alves et al. (2004) and Santos Filho (this issue). Among 8218 female pupae collected from 34 combs and 5 colonies, 8209 were workers, 1 was a miniature queen reared from a worker cell and 8 were normal-sized queens reared from royal cells. ${ }^{c}$ Estimate based on the fore mentioned data of Alves et al. (2003) and data of Ribeiro et al. (2003), who showed that one exceptional comb contained 19 workers, 15 miniature queens and 6 queens in royal cells; ${ }^{\mathrm{d}}$ Maximum percentage observed in combs examined; ${ }^{\mathrm{e}}$ Among 59 recently emerged virgin queens collected from 11 colonies, 51 were miniature (Ribeiro and Alves, 2001); ${ }^{\mathrm{f}}$ Estimate based on the collection of recently emerged virgin queens. Across 13 colonies, and excluding two exceptional colonies that produced a very high number of virgin queens, 10 out of $68(15 \%)$ virgin queens were miniature (Ribeiro et al., accepted). With data from the two exceptional colonies included, 50 out of 112 (45\%) were miniature (Ribeiro et al., 2006); g Wenseleers et al., 2005, also see Figure 3; ${ }^{\text {h }}$ Ribeiro, unpublished data; see Figure 3; ${ }^{\text {i }}$ Among a total of 64 colonies examined by Imperatriz-Fonseca and Kleinert-Giovannini (1989), Nogueira-Ferreira et al. (2000) and Wenseleers et al. (2005), 13 were headed by miniature queens; ${ }^{j}$ Among 71 queens from 61 colonies, 10 were headed by miniature queens (Ribeiro et al., accepted); ${ }^{\mathrm{k}}$ Miniature mother queens have a reduced egg-laying rate (Ribeiro and Alves, 2001) and their ovaries weigh less than those of normal-sized queens (Wenseleers et al., 2005); ${ }^{1}$ Ribeiro et al., accepted; ${ }^{\mathrm{m}}$ The average lifespan of miniature mated queens and normal-sized mated queens 22.75 months (S.D. 14.64, $n=4$ ) and 15.45 months (S.D. 15.08, $n=49$ ), respectively (Ribeiro, unpublished data) and are not significantly different (Mann-Whitney $U$ test, $P=0.22$ ); ${ }^{\mathrm{n}}$ The rate at which miniature queens head colonies (20\%) is significantly lower than the rate at which they are reared from combs (86\%) (Fisher's exact test, $P<0.00001)$. There are also data to show that small-sized queens are selectively eliminated by workers, but that large queens are stored in wax prisons for later use (Imperatriz-Fonseca and Kleinert-Giovannini, 1989; Imperatriz-Fonseca, 1990); ${ }^{\circ}$ It is unclear whether the rate at which miniature queens head colonies (14\%) is different from the rate at which they are reared, because estimates of the rearing rate are so variable (11-53\% of all queens reared miniature, see above). Normal queens, however, are more likely than miniature queens to be stored in queen prisons for potential later use, suggesting that some form of discrimination is going on (normal queens: 63/68 $=93 \%$ imprisoned, miniature queens: $2 / 10=20 \%$ imprisoned) (Fisher's exact test, $\left.P=2 \times 10^{-6}\right)$.

* This calculations considered that from the 6 royal cells 6 normal queens emerged, although 5 of them had very small sizes and were classified previously as miniature queens by the discriminant function (Ribeiro et al., 2006; see footnote). From the 6 royal cells mentioned for this colony (Ribeiro et al., 2003), only one gave rise to a normal-sized queen; from the other 5 royal cells small queens emerged. The same was observed sporadically also for other colonies which produced queens at lower rates (Ribeiro, unpublished data). There are three possibilities to explain this fact. The first is that the royal cell occasionally may contain less food. But generally the queen refuses to lay an egg when the cell has not the adequate amount of food. The second hypothesis is that the royal cell was not build as large as a typical royal cell, but slightly smaller, as Juliani (1967) observed royal cells of medium size. Finally, the last hypothesis is that some normal-sized cells may be transformed in royal cocoons afterwards, as occurs in Frieseomelitta (Faustino et al., 2002). Indeed, in several occasions it was observed that royal cocoons also in P. remota had a strange appearance (Ribeiro, unpublished data). Up to the moment we cannot give an answer for this question. Only measurements on the cells' size and queens' size simultaneously would bring some light to the problem. 


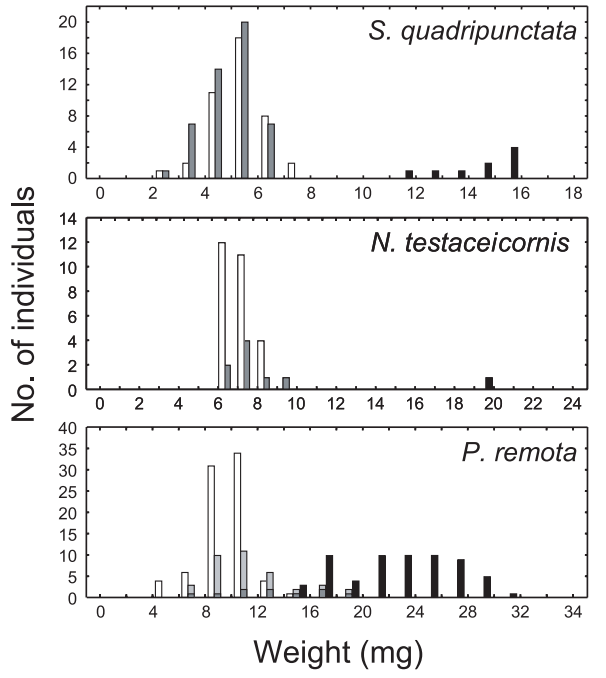

Figure 3. Weights of workers (white), miniature queens (grey) and normal queens (black) in Schwarziana quadripunctata (top, Wenseleers et al., 2005), Nannotrigona testaceicornis (middle, Imperatriz-Fonseca et al., 1997 and Wenseleers and Alves, unpublished data) and Plebeia remota (bottom, Ribeiro, unpublished data). In S. quadripunctata and $N$. testaceicornis, the weight of miniature queens is not significantly different from that of workers, but normal-sized queens are ca. twice as heavy ( $S$. quadripunctata: dry weight miniature queens: $\bar{x}=5.40 \mathrm{mg}, S . D .=0.96, n=42$; workers: $\bar{x}=5.08 \mathrm{mg}, S . D .=0.87, n=49$; normal queens: $\bar{x}=14.32 \mathrm{mg}, S . D .=1.49, n=9 ; N$. testaceicornis: fresh weight miniature queens: $\bar{x}=7.67 \mathrm{mg}$, S.D. $=0.88, n=8$; workers: $\bar{x}=7.13 \mathrm{mg}, S . D .=$ $0.63, n=27$; normal queens: $\bar{x}=19.37 \mathrm{mg}, n=$ 1). This shows that larvae can control their own caste development, and become miniature queens even under worker levels of nutrition. In $P$. remota, self-determination only occurs in some colonies. In two colonies that produced a very high number of miniature queens, miniature queens (light grey) and workers (white) had fresh weights that were not significantly different from each other, but normal queens were much heavier (miniature queens: $\bar{x}=11.10 \mathrm{mg}, S . D .=2.90, n=27$; workers: $\bar{x}=$ $10.34 \mathrm{mg}, S . D .=1.76, n=34$; normal queens: $\bar{x}=18.57 \mathrm{mg}, S . D .=1.63, n=3)$. However, in the remaining colonies, miniature queens (dark grey) had a weight that was intermediate between that of workers and normal-sized queens (miniature queens: $\bar{x}=13.20 \mathrm{mg}, S . D .=3.76, n=10$; workers: $\bar{x}=9.61 \mathrm{mg}, S . D .=1.67, n=46$; normal queens: $\bar{x}=22.75 \mathrm{mg}, S . D .=4.06, n=59$ ). cells can likely determine their own caste fate, as they can develop as queens even under worker levels of nutrition (Tab. II; Wenseleers et al., 2005). It also rejected the earlier hypothesis that queens arise as a result of accidental overprovisioning of cells (Campos and Costa, 1989). On the other hand, it is still possible that miniature queens and workers consume the same amount, but different-quality, food (Ribeiro, 2004a). Although previous studies have found no difference in the quality of the food provisioned into worker and royal cells (Hartfelder, 1987; Hartfelder and Engels, 1989), in S. quadripunctata, a 70-fold difference in the protein content of larval food has been found across cells (Castilho-Hyodo, 2001; Ribeiro, 2004a). Nevertheless, it has been observed that miniature queens are produced from random locations inside the comb (Wenseleers et al., 2005). This at least shows that miniature queens are not reared in some special type of cell in a particular region of the comb.

In further support of the caste conflict hypothesis, Wenseleers et al. (2005) found that miniature queens were vastly overproduced relative to normal-sized queens. By examining 90 combs from 19 colonies, it was found that $86 \%$ (68 out of 79 ) of all queens produced were small-sized and reared from worker cells (Tab. II). An independent estimate based on the collection of recently emerged queens from another 11 colonies gave almost the same result, with $86 \%$ (51 out 59) being miniature (Ribeiro and Alves, 2001; Ribeiro, unpublished data). These high rates of miniature queen production are consistent with an excess of females selfishly choosing to become queens. In absolute terms, however, the excess is relatively modest as only $0.6 \%$ of the females in worker cells develop as miniature queens (Wenseleers et al., 2005). That this figure is much lower than the predicted maximum $(20 \%$, given single mating and absence of worker produced males, Tóth et al., 2003) can be explained given that there likely are costs associated with developing as a miniature queen, and that these costs can reduce the optimum probability to develop as a queen (Wenseleers et al., 2004a). Two such costs have been documented. The first is a fecundity 
cost. Observation of a colony headed by a miniature queen and two colonies headed by normal-sized queens showed that the miniature queen had a lower egg-laying rate than the two others (Ribeiro and Alves, 2001). This is perhaps linked to differences in ovarioles numbers (Camargo, 1974; Cruz-Landim et al., 1998). The ovaries of miniature queens have also been calculated to weigh significantly less than those of normal-sized queens (Wenseleers et al., 2005) and miniature queens have been observed to lay eggs that are smaller than those of normal-sized queens (Ribeiro and Castilho-Hyodo, 2004). Aside from differences in fecundity, miniature queens might also have a shorter lifespan than normal-sized queens. However, no data are available on this for $S$. quadripunctata.

A second major cost is that during supersedure or swarming events, miniature queens may be disadvantaged relative to normal-sized queens (Wenseleers et al., 2004a). This is shown by the fact that the rate at which miniature queens head colonies $(20 \%)$ is significantly lower than the rate at which they are reared (86\%) (Wenseleers et al., 2005). The disadvantage could be caused by several factors. For example, miniature queens might have a lower capability to fly and be less successful on a nuptial flight or males might prefer to mate with normal-sized queens (Ribeiro, 2004a). Workers might also discriminate against miniature queens and prefer a normal-sized queen to head their colony (Wenseleers et al., 2004a, 2005). In fact, Imperatriz-Fonseca and Kleinert-Giovannini (1989) and Imperatriz-Fonseca (1990) reported that whereas large queens are usually confined in special queen prisons for later use, miniature queens are not and are frequently eliminated by workers (Fig. 2d). In one observation, a colony produced 11 miniature queens and one normal-sized queen. The big gyne was imprisoned, but the miniature queens were all killed (Imperatriz-Fonseca, 1990). ImperatrizFonseca and Darakjian (1993) also mentioned that queen prisons generally contain large queens. Our own results confirm that there is such a bias, since 1 out of 7 normal-sized virgin queens $(14 \%)$ that were collected from colonies were found to be imprisoned vs. only
4 out of 51 miniature ones (7.8\%) (Wenseleers and Alves, unpublished data). Although this difference is not significant (Fisher's exact test, $P>0.05)$, it likely would be in a larger sample.

Relatively little information is available to support or reject the insurance hypothesis (Hypothesis 2). Levels of miniature queen production are such that they could represent an effective insurance in case of accidental death of the queen and are not so high that their production would entail a big cost. On the other hand, the fact that the workers build queen prisons in which they can keep virgin queens alive for many months (Camargo, 1974; Imperatriz-Fonseca and Kleinert-Giovannini, 1989; Imperatriz-Fonseca, 1990; ImperatrizFonseca and Darakjian, 1993) would seem to argue against the necessity for such an additional insurance mechanism. The fact that workers frequently eliminate miniature queens (Fig. 2d) also suggests that they are produced in excess, and that the reason for their production has to be sought at the individual and not colony-level.

\subsection{Plebeia remota}

Imperatriz-Fonseca et al. (1975) first discovered that in $P$. remota, miniature queens also may be reared from worker cells and may be produced alongside large queens reared from specialised royal cells. As in S. quadripunctata, miniature queens may occasionally be reared at a high rate. One colony was found to produce 46 gynes in only two months. From the 23 measured gynes, 21 were miniature. A comb from another colony produced 21 gynes, 20 of which were miniature queens (Ribeiro et al., 1998, 2003, 2006, this work).

Overall miniature queens in $P$. remota are produced more sporadically and at a lower rate than in $S$. quadripunctata. For example, among 8218 female pupae collected from 5 colonies, 8209 were workers, 8 were normal-sized queens reared in royal cells and only one was a miniature queen reared in a worker cell (Santos-Filho et al., 2006, this issue). This implies that only $0.01 \%$ of all 
females in worker cells develop as miniature queens and that only $11 \%$ of all queens reared are miniature. A similar estimate of $15 \%$ of all virgin queens reared (10 out of 68) being miniature was obtained based on the collection of recently emerged virgin queens (Ribeiro et al., 2006). Adding the data from the two exceptional colonies mentioned above increases the estimates somewhat, but not greatly (Tab. II). The percentage of females in worker cells that develop as miniature queens then becomes $0.2 \%$, and the percentages of queen pupae and newly emerged queens that are miniature become 53\% and 45\% (Tab. II).

The low rate of miniature queen production in the majority of the colonies might suggest that they are nonadaptive (Hypothesis 3), however the fact that miniature queens can successfully head colonies shows otherwise (Ribeiro and Imperatriz-Fonseca, 2000; Ribeiro et al., 2006). In fact, Ribeiro et al. (2006) found that $14 \%$ of all colonies (10 out of 71) were headed by miniature queens (Tab. II, Fig. 2f). Given the high fitness benefits that miniature queens obtain, an adaptive explanation thus needs to be sought for their production. The typical low rate of miniature queen production might be consistent with the insurance hypothesis (Hypothesis 2). On the other hand, the caste conflict hypothesis can better explain the significant queen overproduction seen in some of the colonies (Hypothesis 1).

A comparison of the weights of miniature queens and workers supports such a dual explanation (Ribeiro, unpubl. data, Fig. 3). Considering both colonies that produced an exceptionally high number of miniature queens, queens and workers had fresh weights that were not significantly different from each other, whereas normal-sized queens were significantly heavier (Fig. 3p). This supports the hypothesis that in these colonies, larvae developed as queens despite worker levels of nutrition, and that an excess chose to do so. By contrast, in the remaining colonies miniature queens had weights that were significantly higher than those of workers although also significantly lower than those of normal-sized queens (Fig. 3p). This shows that in these colonies, the amount of food provisioned into cells did to some extent constrain their development. Why this variation exists is unknown, but one possibility is that only some colonies carry the trait that makes larvae selfishly develop as queens and that colony levels costs prevent the trait from reaching a high frequency in the population. Or it is also possible that occasionally larval food has a higher quality as suggested for $S$. quadripunctata.

That the rate at which females in worker cells develop as miniature queens is only $0.01-$ $0.2 \%$, and much below the maximum rate of $20 \%$ predicted under the caste conflict hypothesis (Wenseleers et al., 2004a) suggests that there are also costs associated with developing as a miniature queen. Ribeiro et al. (2006) tested whether miniature queens experience a fecundity cost. Surprisingly, however, miniature queens had the same egglaying rate as normal-sized queens. Both also had same number of number of ovarioles per ovary (Ribeiro, 1998; Ribeiro and Alves, 2001). On the other hand, as for S. quadripunctata, miniature queens lay smaller eggs than normal-sized queens. This may be related to queen nutrition and, therefore to colony condition (Ribeiro, 2004b).

Miniature queens also have similar longevity as normal-sized queens (Ribeiro, unpubl. data; Tab. II), and both queen morphotypes have been observed heading colonies for more than 4 years.

Finally, it is uncertain whether miniature queens have lower chances than normal-sized queens of being chosen as a new queen (Tab. II). It is unclear, for example, whether the rate of which miniature queens head colonies $(14 \%)$ may be lower than the rate at which they are reared. In fact estimates of the rearing rate are so variable (11-53\%, Tab. II). Normal-sized queens, however, appear more likely than miniature queens to be stored in queen prisons for potential later use, suggesting that some form of discrimination is going on (normal-sized queens: 63/68 $=93 \%$ imprisoned, miniature queens: $2 / 10=20 \%$ imprisoned) (Fisher's exact test, $P=2 \times 10^{-6}$ ). It is unknown whether any discrimination might also occur at a later stage, e.g. during mating, as all attempts to get virgin queens mated in the lab have failed. 


\subsection{Other species}

Data on miniature queens are rare for most other species and, in fact, for most genera of stingless bees the presence of miniature queens simply has not been investigated. Miniature queens have been observed in Cephalotrigona capitata (von Ihering, 1903; Schwarz, 1948), P. julianii (Juliani, 1967), P. emerina (Kleinert, pers. comm.) and $P$. droryana (Imperatriz-Fonseca, pers. comm.). However, little more is known beyond the fact that they occur and it is not known whether they can successfully head colonies. In $P$. pugna in litt., we discovered a miniature queen in a comb which also contained one normal queen in a royal cell (Wenseleers and Alves, unpubl. data). The miniature queen had a fresh weight $(7.60 \mathrm{mg})$ that was slightly higher than that of workers $(\bar{x}=6.14 \mathrm{mg}$, $S . D .=0.62 \mathrm{mg}, n=20$ ) but much lower than that of normal queens $(\bar{x}=33.55 \mathrm{mg}, S . D .=$ $3.89 \mathrm{mg}, n=2)$. As for the species above, however, it is not known whether the miniature queens can succesfully head colonies. More data are available on the miniature queens of $N$. testaceicornis (Imperatriz-Fonseca et al., 1997). In this species, a single comb was found to contain 5 miniature queens and another contained 8 miniature queens plus a normalsized queen in a royal cell (Imperatriz-Fonseca et al., 1997). These results suggest that in this species, miniature queens may also be produced at a high rate and are overproduced relative to normal-sized queens. Furthermore, in support of caste self-determination, newly emerged miniature queens and workers had weights which were not significantly different from each other (Imperatriz-Fonseca et al., 1997). Both these observations support the caste conflict hypothesis (Hypothesis 1). The similar weights of queens and workers also reject the hypothesis that miniature queens arise from cells that are overprovisioned (Hypothesis 3, Campos et al., 1986). The miniature $N$. testaceicornis queens were found to be normal in behaviour and morphology, but had a smaller number of ovarioles per ovary, 4 to 8 , as opposed to 12 for normal-sized queens (Imperatriz-Fonseca et al., 1997). This implies they are probably less fecund.
A final and most intriguing case of miniature queen production has been discovered by Freitas and Paxton (pers. comm.). When they examined combs from 3 colonies of $P$. mosquito collected at Fortaleza, Ceará, NE Brazil, they found that the cells contained 105 workers, 73 miniature queens, 1 normal-sized queen and 84 males. This means that an astounding $40 \%$ of all females in worker cells had developed as miniature queens and that $96 \%$ of all queens produced were miniature. This represents a level of queen overproduction that is unseen in any other stingless bee, including S. quadripunctata and $P$. remota (Tab. II) and even Melipona, and supports the prediction of caste conflict theory (Hypothesis 1) that a great excess of females can be selected to develop as queens. In any case, the level of excess queen production is so high that for this species that the insurance hypothesis (Hypothesis 2) most definitely can be rejected. The fact that the excess is at or even higher than the predicted maximum level (20\%; Wenseleers et al., 2004a) also suggests that in this species miniature queens do not experience any costs relative to normalsized queens, that is that they have equal fecundity and are not discriminated against during swarming. This prediction remains to be tested.

\section{PHYLOGENETIC CONSIDERATIONS AND COMPARISON TO MELIPONA}

The available morphological and molecular phylogenies of stingless bees (Engel, 2000; Costa et al., 2003) suggest that the presence of miniature queens is a derived characteristic that evolved at least three times independently, once in the related genera Plebeia and Schwarziana, once in Nannotrigona and once in Cephalotrigona. If miniature queens are indeed a selfish adaptation of developing females intended to evade a worker fate, then this means that resistance to nutritionally controlled caste determination has evolved multiple times independently, and that nutritional caste determination is inherently unstable as a social control mechanism (Ratnieks 
and Wenseleers, 2005). Nevertheless, to determine the exact number of independent origins, miniature queens should be looked for more systematically in a greater range of genera.

Another question which deserves attention is whether Melipona queens may be homologous to miniature queens. Indeed, the similarities are striking. Like miniature queens, Melipona queens are reared from worker-sized cells, are reared in excess, and superfluous queens are killed by the adult workers soon after they emerge from their cells (Silva et al., 1972; Koedam et al., 1995; Wenseleers et al., 2004b). These similarities suggest that the evolutionary pressure that led to the evolution of small-sized queens is identical in both cases, and that both are caused by selection on females to evade a worker fate. One difference with the species that produce miniature queens, however, is that Melipona does not build royal cells. We suggest that this habit may have been secondarily lost. Given that Melipona produces queens at such a high rate (up to $25 \%$ of all females develop as queens, Kerr, 1950, 1969; Wenseleers et al., 2003, 2004b; Wenseleers and Ratnieks, 2004), it may be the case that any large queens reared from royal cells would statistically have such a low chance of ever successfully heading a daughter swarm that the workers would be better off not producing any royal cells at all. Indeed, a secondary loss of the habit of building royal cells is also seen in the genera Frieseomelitta and Leurotrigona, where caste is also partly individually determined, and larvae develop as queens by biting through their cell wall and consuming the provision mass of a neighbouring cell (Terada, 1974; Faustino et al., 2002; Fig. 1c).

If miniature queens and Melipona queens do indeed share a common evolutionary history, one may also wonder whether they are produced by the same mechanism. For Melipona, Kerr (1950) famously proposed that caste determination is controlled by a 2-loci 2-allele system whereby only double heterozygotes could develop as queens. This would lead to the production of $25 \%$ queens on average. Given that queen production in Melipona is frequently lower than this, in the range of 5-15\% (Kerr, 1969; Wenseleers and Ratnieks,
2004), the original theory was later slightly modified and it was proposed that the double heterozygotes only have the capacity to develop as queens, but only do so in response to good environmental or nutritional conditions (Kerr, 1969; Velthuis and Sommeijer, 1991). A genetic caste determination mechanism was also assumed in the evolutionary models of Ratnieks (2001) and Wenseleers et al. (2003), which were intended to provide an ultimate explanation for the high levels of queen production in Melipona. However, they instead assumed that all females in the colony develop as queens with a fixed probability that is under the control of a single genetic locus.

Given the similarity with Melipona queens, we think that it is likely that the development of miniature queens is also under the control of a genetic mechanism (Wenseleers et al., 2004a). Nevertheless, more work is needed to elucidate whether a variant of the Kerr mechanism or some other system is involved. In both Melipona and Schwarziana, however, it is known that topical application of juvenile hormone onto cocoon spinning larvae results in the production of queens (Campos and Costa, 1989; Velthuis and Sommeijer, 1991). Hence, it would be expected that production of this hormone at least forms part of the genetic pathway that controls queen determination.

\section{COMPARISON TO MICROGYNE QUEENS IN ANTS}

Outside the stingless bees, miniature queens have not been recorded in either bumblebees or honeybees. However, they have been recorded in ants, where they are referred to as microgyne queens (Bourke and Franks, 1991; McInnes and Tschinkel, 1995; Hamaguchi and Kinomura, 1996; Rüppell et al., 1998, 2001a, b, 2002; da Hora et al., 2001). As for stingless bees, Bourke and Ratnieks (1999) proposed that miniature queens in ants reflect a strategy to evade an intended worker fate. For Leptothorax rugatulus, however, Rüppell et al. (1998, 2001a, b, 2002), considered it more likely that miniature queens are produced as part of a dispersal polymorphism, and as an adaptation 
to dependent colony founding. In fact, selfdetermination in ants is less well-supported than in stingless bees. In L. rugatulus, for example, it has been shown that microgyne queens are significantly heavier than workers (Rüppell et al., 2002). On the other hand, it has been shown that the queen morphs in L. rugatulus are to some extent genetically determined (Rüppell et al., 2001b). Overall, however, more work is needed to conclusively determine the ultimate causes of microgyne queens in ants.

\section{CONCLUSION}

Miniature queens in stingless bees were once considered a mere curiosity but as we have shown their importance has been vastly underestimated. First, they offer fundamental insight into the pathways that may have led to the different caste determination systems in stingless bees. In particular, the species that produce miniature queens share characteristics of both the genetic caste determination of Melipona and the nutritional caste determination of the other genera and thus provide a kind of a relict "stepping stone" between the two. Second, we have shown that miniature queens provide among the best support for the hypothesis that there is a conflict over the caste fate of developing individuals in insect societies (Bourke and Ratnieks, 1999; Ratnieks et al., 2006). In particular, data from several species show that individual females benefit from developing as small-sized queens even when reared from a worker cell, since they are frequently observed heading colonies (Ribeiro and Alves, 2001; Ribeiro et al., 2006; Wenseleers et al., 2005). In addition, and in accordance with the theory, there is increasing evidence that the decision to develop as a miniature queen is under individual control of the developing larvae (Tab. II, Fig. 3). Finally, as predicted by the caste conflict hypothesis (Bourke and Ratnieks, 1999; Wenseleers et al., 2003, 2004a), an excess of females frequently develop as miniature queens (Tab. II). The predictive power of these ultimate explanations is testimony to the great progress that we have made in understanding why miniature queens are produced. Nevertheless, many questions still remain, and no doubt, more discoveries still lie ahead of us.

\section{ACKNOWLEDGEMENTS}

We are grateful to Vera L. Imperatriz-Fonseca for support and to Francis L.W. Ratnieks for discussion. We also thank Breno M. Freitas and Robert Paxton for allowing us to cite their unpublished study of Plebeia mosquito. This research was supported by Brazilian agencies $\mathrm{CNPq}$ (proc. n. 522121/97-7, 370824/2000-8 and proc. n. 35.0781/2004.4) and FAPESP (through a grant to the first author, proc. n. 98/01679-5).

Résumé - Reines miniatures chez les abeilles sans aiguillon : données de base et hypothèses concernant l'évolution. Les abeilles sans aiguillon possèdent deux mécanismes principaux qui conditionnent la différenciation des castes et l'élevage des reines. Chez le genre Melipona, la caste est déterminée génétiquement et les reines sont élevées dans des cellules d'ouvrières, qui servent aussi à élever les mâles. Chez les autres genres, la caste est déterminée par la nutrition et les reines sont élevées dans de grandes cellules royales construites en général sur le pourtour du rayon. Il existe néanmoins un troisième système intermédiaire (Fig. 1). Certaines abeilles sans aiguillon produisent à la fois de grosses reines à partir de cellules royales et des reines «miniatures » à partir des cellules d'ouvrières. Nous passons en revue les connaissances concernant les reines miniatures et évaluons les principales hypothèses du pourquoi elles sont produites sur le plan de l'évolution (Tab. I). L'une des hypothèses - selon laquelle les reines miniatures sont des femelles qui par intérêt échappent au destin des ouvrières - a reçu un soutien significatif. Il y a en particulier de bonnes preuves pour que la décision de devenir une reine miniature puisse être sous le contrôle génétique des femelles elle-mêmes en cours de développement et ne soit pas limitée par la nutrition. En outre des données provenant de plusieurs espèces montrent que les femelles bénéficient d'une valeur d'adaptation (fitness) significative en agissant ainsi, puisque les reines miniatures ont fréquemment été observées à la tête de colonies et qu'elles sont très productives. Le tableau II discute chez deux espèces (Schwarziana quadripunctata et Plebeia remota) le taux de production des reines miniatures vierges et le succès reproductif des reines miniatures fécondées. Chez certaines espèces, les reines miniatures peuvent avoir une fécondité réduite ou des chances amoindries d'être choisies comme nouvelle reine. Cela montre que la stratégie peut avoir aussi des coûts (Tab. III). On suggère que les reines du genre Melipona, elles aussi élevées dans des 
cellules d'ouvrières, ont la même origine évolutive que les reines miniatures.

\section{abeilles sans aiguillon / dimorphisme / reine mi-} niature / conflit de caste / Apidae / Meliponini

Zusammenfassung - Zwergköninnen bei Stachellosen Bienen: grundlegende Fakten und $\mathrm{Hy}$ pothesen zu ihrer Evolution. Stachellose Bienen verfügen über zwei hauptsächliche Mechanismen zur Determination der Kasten und Aufzucht von Königinnen. In der Gattung Melipona liegt eine genetische Kastendetermination vor, und die Zellen in denen Königinnen aufgezogen werden, sind von gleicher Grösse wie die von Arbeiterinnen und Männchen. In den anderen Gattungen sind die Kasten trophisch determiniert, und Königinnen werden in grossen Königinnenzellen aufgezogen, die speziell am Rand der Brutwaben gebaut werden. Es existiert aber noch ein drittes System, das genau zwischen den beiden obengenannten liegt (Abb. 1). Einige Stachellosen Bienen produzieren gleichzeitig grosse Königinnen in Königinnenzellen und kleine "Zwergköniginnen" in Arbeiterinnenzellen. Wir berichten in diesem Übersichtsartikel, was über Zwergköniginnen bei Stachellosen Bienen bekannt ist und nehmen die wichtigsten evolutiven Hypothesen zu ihrer Produktion unter die Lupe (Tab. I). Unsere Hypothese, dass Zwergköniginnen Weibchen sind, die eigennützig ihrem eigentlichen Arbeiterinnenschicksal entwichen sind, erhielt dabei signifikante Unterstützung, insbesondere, dass die Entscheidung sich in eine Zwergkönigin zu entwickeln eine genetische Grundlage hat und nicht auf einem Nahrungsunterschied beruht. Ausserdem zeigen Daten von verschiedenen Arten, dass solche Weibchen einen signifikanten Zuwachs ihrer Fitness aufweisen, da Zwergköniginnen bei einigen Arten häufig als dominante und sehr produktive Weibchen in den Kolonien dieser Arten zu finden sind. Bei anderen Arten hingegen haben Zwergköniginnen eine reduzierte Fekundität und geringere Chancen als neues Oberhaupt der Kolonie ausgewählt zu werden. Dies zeigt, dass diese Strategie auch Kosten mit sich bringt (Tab. III). Königinnen der Gattung Melipona, die allesamt in Zellen von Arbeiterinnengrösse aufgezogen werden, könnten demnach den gleichen evolutiven Ursprung haben wie Zwergköniginnen.

Königinnendimorphismus / Zwergköniginnen / Stachellose Bienen / Kastenschicksalskonflikt / Apidae / Meliponini

\section{REFERENCES}

Alves D.A., Ribeiro M.F., Imperatriz-Fonseca V.-L. (2003) A conservação das abelhas sociais nativas (Apidae, Meliponinae) e a produção de rainhas em
Plebeia remota Holmberg 1903, in: VI Congr. de Ecologia do Brasil, pp. 217-219.

Alves D.A., Ribeiro M.F., Santos-Filho P.S., Imperatriz-Fonseca V.L. (2004) Production of gynes and males in Plebeia remota Holmberg 1903 (Apidae, Meliponini), in: Proc. 8th IBRA Intern. Conf. on Tropical Bees and VI Encontro Sobre Abelhas, p. 753.

Bourke A.F.G., Franks N.R. (1991) Alternative adaptations, sympatric speciation and the evolution of parasitic, inquiline ants, Biol. J. Linn. Soc. 43, 157-178.

Bourke A.F.G., Ratnieks F.L.W. (1999) Kin conflict over caste determination in social Hymenoptera, Behav. Ecol. Sociobiol. 46, 287-297.

Camargo C.A. (1972) Determinação de castas em Scaptotrigona postica Latreille (Hymenoptera, Apidae), Rev. Bras. Biol. 32, 133-138.

Camargo J.M.F. (1974) Notas sobre a morfologia e biologia de Plebeia (Schwarziana) quadripunctata quadripunctata (Hymenoptera, Apidae, Meliponinae), Stud. Entomol. 17, 433-470.

Campos L.A.O., Costa M.A. (1989) Determinação de sexo em abelhas. XXVII. Determinação das castas em Schwarziana quadripunctata (Hymenoptera, Apidae), Rev. Bras. Biol. 49, 121-123.

Campos L.A.O., Coelho C.D.P. (1993) Determinação de sexo em abelhas. XXX. Influência da quantidade de alimento e do hormônio juvenil na determinação das castas em Partamona cupira helleri (Hymenoptera, Apidae, Meliponinae), Rev. Bras. Zool. 10, 449-452.

Campos L.A.O., Faria G.M., Pires C.S.S., Drumond M.S., Lacerda L.M. (1986) Determinação das castas em Nannotrigona testaceicornis (Hymenoptera, Apidae), in: Res. XIII Congr. Bras. Zool., Cuiabá, Brazil, p. 101.

Castilho-Hyodo V.C.C. (2001) Rainha ou operária? Um ensaio sobre a determinação de castas em Schwarziana quadripunctata (Lepeletier, 1836) (Hymenoptera, Apidae, Meliponini), PhD Thesis, University of São Paulo, São Paulo, 134 p.

Costa L.M. (1977) Estudos em rainhas de Schwarziana quadripunctata, Ciência e Cultura 49, 706.

Costa M.A., del Lama M.A., Melo G.A.R., Sheppard W.S. (2003) Molecular phylogeny of the stingless bees (Apidae, Apinae, Meliponini) inferred from mitochondrial 16S rDNA sequences, Apidologie $34,73-84$

Cruz-Landim C.D., Reginato R.D., ImperatrizFonseca V.L. (1998) Variation on ovariole number in Meliponinae (Hymenoptera, Apidae) queen's ovaries, with comments on ovary development and caste differentiation, Pap. Avulsos Zool. São Paulo 40, 289-296.

da Hora R.R., Feneron R., Valenzuela J., Favila M.E., Fresneau D. (2001) Queen-size dimorphism in the ant Ectatomma tuberculatum (Hymenoptera: Formicidae: Ponerinae), Sociobiology 38, 407420 . 
Darchen R., Delage-Darchen B. (1971) Le déterminisme des castes chez les Trigones (Hyménoptères Apidés), Insectes Soc. 18, 121-134.

Engel M.S. (2000) A new interpretation of the oldest fossil bee (Hymenoptera: Apidae), Am. Mus. Novit. 3296, 1-11.

Engels W., Imperatriz-Fonseca V.L. (1990) Caste development, reproductive strategies, and control of fertility in honey bees and stingless bees, in: Engels W. (Ed.), Social Insects: An Evolutionary Approach to Castes and Reproduction, SpringerVerlag, Berlin, Heidelberg, pp. 167-230.

Faustino C.D., Silva-Matos E.V., Mateus S., Zucchi R. (2002) First record of emergency queen rearing in stingless bees (Hymenoptera, Apinae, Meliponini), Insectes Soc. 49, 111-113.

Hamaguchi K., Kinomura K. (1996) Queen-size dimorphism in the facultatively polygynous ant Leptothorax spinosior (Hymenoptera: Formicidae), Sociobiology 27, 241-251.

Hartfelder K. (1987) Caste differentiation in stingless bees: a comparative analysis of larval food from 7 species. in: Eder J., Rembold H. (Eds.), Chemistry and Biology of Social Insects, Verlag, München, p. 174.

Hartfelder K., Engels W. (1989) The composition of larval food in stingless bees: evaluating nutritional balance by chemosystematic methods, Insectes Soc. 36, 1-14.

Imperatriz-Fonseca V.L. (1976) Studies on Paratrigona subnuda (Moure) Hymenoptera, Apidae, Meliponinae - I: Members of the colony, Rev. Bras. Entomol. 20, 101-112.

Imperatriz-Fonseca V.L. (1990) Swarming activity in Schwarziana quadripunctata (Apidae, Meliponinae), in: Social insects and the environment, Oxford \& IBH Publ. Co, Bombay, India, pp. 744-745.

Imperatriz-Fonseca V.L., Kleinert-Giovannini A. (1989) Atividades de rainhas virgens em Plebeia (Schwarziana) quadripunctata (Apidae, Meliponinae), in: Res. do I Simpósio LatinoAmericano sobre Insetos Sociais Neotropicais (Rio Claro), p. 11.

Imperatriz-Fonseca V.L., Darakjian P. (1993) Notas sobre o comportamento das rainhas virgens de Schwarziana quadripunctata (Apidae, Meliponinae), Ciência e Cultura 45, 912.

Imperatriz-Fonseca V.L., Zucchi R. (1995) Virgin queens in stingless bee (Apidae, Meliponinae) colonies: a review, Apidologie 26, 231-244.

Imperatriz-Fonseca V.L., Oliveira M.A.C., Iwama S. (1975) Notas sobre o comportamento de rainhas virgens de Plebeia (Plebeia) remota Holmberg (Apidae, Meliponinae), Ciência e Cultura 27, 665-669.

Imperatriz-Fonseca V.L., Cruz-Landim C., Moraes R.L.M.S., Zucchi R. (1994) Dwarf queens in Nannotrigona testaceicornis, in: Int. Congr. IUSSI 12, Paris, p. 442.
Imperatriz-Fonseca V.L., Cruz-Landim C., Moraes R.L.M.S. (1997) Dwarf gynes in Nannotrigona testaceicornis (Apidae, Meliponinae, Trigonini), Behaviour, exocrine gland morphology and reproductive status, Apidologie 28, 113-122.

Juliani L. (1962) O aprisionamento de rainhas virgens em Trigonini, Bol. Univ. Paraná Zool. 20, 1-11.

Juliani L. (1967) A descrição do ninho e alguns dados biológicos sobre a abelha Plebeia julianii Moure, Rev. Bras. Entomol. 12, 31-58.

Kerr W.E. (1950) Genetic determination of castes in the genus Melipona, Genetics 35, 143-152.

Kerr W.E. (1969) Some aspects of the evolution of social bees (Apidae), in: Dobzhansky T., Hecht M.K., Steere W.C. (Eds.), Evolutionary Biology, Vol. 3, Appleton-Century Crofts, New York, pp. 119-175.

Koedam D., Aguilar-Monge I., Sommeijer M.J. (1995) Social interactions of gynes and their longevity in queenright colonies of Melipona favosa (Apidae: Meliponinae), Neth. J. Zool. 45, 480-494.

McInnes D.A., Tschinkel W.R. (1995) Queen dimorphism and reproductive strategies in the fire ant Solenopsis geminata (Hymenoptera: Formicidae), Behav. Ecol. Sociobiol. 36, 367-375.

Michener C.D. (1974) The social behavior of the bees, Harward University Press, Cambridge, Massachussets.

Moo-Valle H., Quezada-Euan J.J.G., Wenseleers T. (2001) The effect of food reserves on the production of sexual offspring in the stingless bee Melipona beecheii (Apidae, Meliponini), Insectes Soc. 48, 398-403.

Moure J.S., Nogueira-Neto P., Kerr W.E. (1958) Evolutionary problems among Meliponinae (Hymenoptera, Apidae), in: Proceedings of the Xth Int. Congr. Entomology, Montreal, pp. 481-493.

Nogueira-Ferreira F.H., Baio M.V., Noll F.B., TidonSklorz R., Zucchi R. (2000) Morphometric study in Schwarziana quadripunctata with emphasis on virgin queens (Hymenoptera, Apidae, Meliponinae), Sociobiology 35, 99-108.

Nogueira-Neto P. (1958) Rainhas prisoneiras, Chácaras \& Quintais 97, 477.

Ratnieks F.L.W. (2001) Heirs and spares: caste conflict and excess queen production in Melipona bees, Behav. Ecol. Sociobiol. 50, 467-473.

Ratnieks F.L.W., Wenseleers T. (2005) Policing insect societies, Science 307, 54-56.

Ratnieks F.L.W., Foster K.R., Wenseleers T. (2006) Conflict resolution in insect societies, Annu. Rev. Entomol. 51, 581-608.

Ribeiro M.F. (1998) Size polymorphism among queens of stingless bees, in: XIIIth Int. Congr. IUSSI, Adelaide, Australia, p. 394.

Ribeiro M.F. (2004a) Miniature queens in stingless bee species - a review, in: Proc. 8th IBRA Intern. 
Conf. on Tropical Bees and VI Encontro Sobre Abelhas, pp. 280-286.

Ribeiro M.F. (2004b) Do the miniature queens of Plebeia remota (Hymenoptera, Apidae, Meliponini) lay smaller eggs than normal-sized ones? in: Abstracts, 52nd ESA Annual Meeting, D0299 [on line] http://esa.confex.com/esa/2004/techprogram/ paper_17932.htm (accessed on 21 February 2006).

Ribeiro M.F., Imperatriz-Fonseca, V.L. (2000) Queen size polymorphism and its role in stingless bees: a populational study, Abstracts, VIII Int. Behaviour Ecology Congr., p. 164.

Ribeiro M.F., Alves D.A. (2001) Size variation in Schwarziana quadripunctata queens (Hymenoptera, Apidae, Meliponini), Rev. Etol. 3, 59-65.

Ribeiro M.F., Castilho-Hyodo V.C.C. (2004) Do the dwarf queens of Schwarziana quadripunctata (Hymenoptera, Apidae, Meliponinae) lay smaller eggs than normal-sized ones? Proc. 8th IBRA Int. Conf. on Tropical Bees and VI Encontro Sobre Abelhas, p. 698.

Ribeiro M.F., Patricio E.F.L.R.A., Imperatriz-Fonseca V.L. (1998) Exceptional production of gynes in a Plebeia remota (Hymenoptera, Apidae, Meliponinae) colony, in: Abstracts XIIIth Int. Congr. IUSSI, Adelaide, Australia, p. 395.

Ribeiro M.F., Imperatriz-Fonseca V.L., Santos-Filho P.S. (2003) Exceptional high queen production in the Brazilian stingless bee Plebeia remota, Stud. Neotrop. Fauna Environ. 38, 111-114.

Ribeiro M.F., Santos-Filho P.S., Imperatriz-Fonseca V.L. (2006) Size variation and egg laying performance in Plebeia remota queens (Hymenoptera, Apidae, Meliponini), Apidologie (in press).

Rüppell O., Heinze J., Hölldobler B. (1998) Sizedimorphism in the queens of the North American ant Leptothorax rugatulus (Emery), Insectes Soc. $45,67-77$.

Rüppell O., Heinze J., Hölldobler B. (2001a) Alternative reproductive tactics in the queen-sizedimorphic ant Leptothorax rugatulus (Emery) and their consequences for genetic population structure, Behav. Ecol. Sociobiol. 50, 189-197.

Rüppell O., Heinze J., Hölldobler B. (2001b) Complex determination of queen body size in the queen size dimorphic ant Leptothorax rugatulus (Formicidae: Hymenoptera), Heredity 87, 33-40.

Rüppell O., Heinze J., Hölldobler B. (2002) Sex ratio variation in a facultatively polygynous ant with size-dimorphic queens, Ethol. Ecol. Evol. 14, 5367.

Schwarz H.F. (1948) Stingless bees (Meliponidae) of the Western Hemisphere, Bull. Am. Mus. Nat. Hist. 90, 1-546.
Santos-Filho P.S., Alves D.A., Eterovic A., ImperatrizFonseca V.L., Kleinert A. (2006) Numerical investment in sex and castes by stingless bees (Apidae, Meliponini): a comparative analysis, Apidologie 37, 207-221.

Silva D.L.N da, Zucchi R., Zucchi R. (1972) Biological and behavioural aspects of the reproduction in some species of Melipona (Hymenoptera, Apidae, Meliponinae), Anim. Behav. 20, 123-132.

Sommeijer M.J., de Bruijn L.L.M., Meeuwsen F.J.A.J., Martens E.P. (2003) Natural patterns of caste and sex allocation in the stingless bees Melipona favosa and $M$. trinitatis related to worker behaviour, Insectes Soc. 50, 38-44.

Terada Y. (1974) Contribuição ao estudo da regulação social em Leurotrigona muelleri e Frieseomelitta varia, $\mathrm{PhD}$ thesis, University of São Paulo, Ribeirão Preto.

Tóth E., Strassmann J.E., Imperatriz-Fonseca V.L., Queller D.C. (2003) Queens, not workers, produce the males in the stingless bee Schwarziana quadripunctata quadripunctata, Anim. Behav. 66, 359-368.

van Benthem F.D.J., Imperatriz-Fonseca V.L., Velthuis H.H.W. (1995) Biology of the stingless bee Plebeia remota (Holmberg): Observations and evolutionary implications, Insectes Soc. 42, 7187.

Velthuis H.H.W., Sommeijer M.J. (1991) Roles of morphogenetic hormones in caste polymorphism in stingless bees, in: Gupta A.P. (Ed.), Morphogenetic Hormones of Arthropods, Rutgers University Press, New Brunswick, pp. 346-383.

von Ihering H. (1903) Biologie der stachellosen Honigbienen Brasiliens, Zool. Jahrb. 19, 179-287.

Wenseleers T., Ratnieks F.L.W. (2004) Tragedy of the commons in Melipona bees, Proc. R. Soc. Lond. B Biol. Sci. 271, S310-S312.

Wenseleers T., Ratnieks F.L.W., Billen J. (2003) Caste fate conflict in swarm-founding social Hymenoptera: an inclusive fitness analysis, J. Evol. Biol. 16, 647-658.

Wenseleers T., Hart A.G., Ratnieks F.L.W. (2004a) When resistance is useless: policing and the evolution of reproductive acquiescence in insect societies, Am. Nat. 164, E154-E167.

Wenseleers T., Hart A.G., Ratnieks F.L.W., QuezadaEuán J.J.G. (2004b) Queen execution and caste conflict in the stingless bee Melipona beecheii, Ethology 110, 725-736.

Wenseleers T., Ratnieks F.L.W., Ribeiro M.F., Alves D.A., Imperatriz-Fonseca V.L. (2005) Workingclass royalty: bees beat the caste system, Biol. Lett. 1, 125-128.

Wilson E.O. (1971) The Insect Societies, Harvard University Press, Cambridge, Massachusetts. 